\title{
Analisis Kepuasan Mahasiswa dalam Menggunakan Sistem Informasi Terpadu Akademik (SITA) Universitas Batanghari Jambi
}

\author{
Osrita Hapsara $^{1}$, Gupron², Andri Yandi ${ }^{3}$ \\ ${ }^{1,2,3}$ Fakultas Ekonomi Universitas Batanghari Jambi \\ Jl. Slamet Ryadi, Broni-Jambi, Indonesia \\ Correspondence email: osritahapsara@yahoo.co.id; gupronalie@gmail.com; andri.yandi@unbari.ac.id
}

\begin{abstract}
This study aims to analyze the effect of system quality, information quality, and service quality on student satisfaction in using the Integrated Academic Information System (SITA) at Batanghari University (Unbari) Jambi. This research was conducted in the Unbari Jambi environment, with the population in this study were students in the Unbari Jambi environment. The sample in the study was 98 students with proportionate random sampling technique. Types and sources of research data consist of primary data, namely data obtained from the opinions of respondents through a research questionnaire, and secondary data, namely data obtained from Unbari Jambi. The data analysis technique used in testing the research hypothesis was multiple linear regression analysis using SPSS version 21.0 for windows. The results of the study found that: 1) system quality has a positive and significant effect on student satisfaction in Unbari Jambi; 2) the quality of information has a significant positive effect on student satisfaction in Unbari Jambi; 3) service quality has a significant positive effect on student satisfaction in Unbari Jambi; and 4) system quality, information quality, and service quality together have a significant effect on the satisfaction of Unbari Jambi students with a contribution of influence of $68.1 \%$ and the remaining $31.9 \%$ is influenced by other factors not included in the scope of this study.
\end{abstract}

Keywords: System Quality, Information Quality, Service Quality, and Student Satisfaction.

\section{Pendahuluan}

Di era global saat ini, perkembangan teknologi informasi dan sistem informasi sangat dibutuhkan oleh khalayak bagi individu maupun perusahaan atau organisasi termasuk institusi pendidikan seperti universitas. Penerapan sistem informasi pada universitas sangat dibutuhkan tujuannya untuk mendapatkan kemudahan, kecepatan, dan ketepatan dalam mengolah data dan atau informasi yang diperoleh. Selain itu pentingnya penggunaan system informasi pada universitas saat ini juga dikarenakan sudah semakin kompleksnya persoalan yang dihadapi oleh perguruan tinggi sebagai organisasi pendidikan. Berdasarkan perihal tersebutlah universitas pun dituntut juga harus memiliki sistem informasi, tak terkecuali pula dengan Univeristas Batanghari (Unbari) yang merupakan salah satu perguruan tinggi swasta di Provinsi Jambi, juga dituntut untuk memiliki system informasi berbasis teknologi, agar proses administrasi akademik dan kemahasiswaan seperti pengisian Kartu Rencana Studi (KRS), pemantauan Kartu Hasil Studi (KHS), informasi kelas dan dosen, serta jadwal kuliah dan ujian dapat di kelola secara sistematis dengan baik. Program Sistem Informasi Terpadu Akademik (SITA) Online diperkenalkan kapada mahasiswa Unbari mulai sejak tahun 2012 lalu. Tujuan disediakannya Sistem Informasi Terpadu Akademik (SITA) Online oleh Unbari adalah untuk membantu mahasiswa dalam mengakses informasi akademik sehingga dapat menentukan keputusan akademiknya secara mandiri.

SITA online diharapkan dapat memperbaiki administrasi akademik mahasiswa pada masing-masing fakultas yang sebelumnya masih dijalankan secara manual. Hal ini diharapkan adanya keselarasan antara sumber daya informasi yang berhubungan yaitu mahasiswa, pengajar dan staf dalam hal ini akademik dan kemahasiswaan dapat terwujud. SIT A online ini juga diharap dapat menyediakan informasi yang akurat, cepat, dan tepat yang pada akhirnya proses ini dapat mempersingkat waktu dengan tidak menguragi kualitas dari informasi dan menujukan hasil yang lebih efisien dalam menyajikan informasi bagi semua pihak. Berdasarkan latar belakang yang telah diuraikan di atas, maka penulis merasa penting dan menarik untuk melakukan kajian yang lebih mendalam mengenai kepuasan mahasiswa dalam penggunaan SITA Unbari.

\section{Landasan Teori \\ Kepuasan}

Kepuasan adalah evaluasi pelanggan tentang produk atau pelayanan, apakah produk atau layanan itu telah memenuhi kebutuhan dan harapan mereka (Akbar dan Parves, 2009). Menurut Lovelock dan Wright (2007) kepuasan pelanggan memainkan peran yang penting karena terdapat perbedaan yang besar dalam loyalitas, antara pelanggan yang sekedar puas dan yang benar- benar puas. Engel (2010) menyatakan bahwa kepuasan adalah perasaan senang atau kecewa seseorang yang berasal dari perbandingan antara kesannya terhadap hasil suatu jasa dan harapanharapannya. Kepuasan merupakan fungsi dari kesan kinerja dan harapan. Jika kinerja berada di bawah harapan, pelanggan akan tidak puas. Jika kinerja melebihi harapan, maka pelanggan akan merasa amat puas atau senang. Dalam 
Osrita Hapsara et al, Analisis Kepuasan Mahasiswa dalam Menggunakan Sistem Informasi Terpadu Akademik (SITA) Universitas Batanghari Jambi

kaitan itu, maka faktor kepuasan pelanggan (customer satisfaction) menjadi elemen penting dalam memberikan atau menambah nilai bagi pelanggan.

Menciptakan dan mencapai kepuasan mahasiswa sebagai pengguna suatu sistem yang diterapkan suatu perguruan tinggi, bukanlah suatu hal yang mudah bagi perusahaan tersebut, mengingat bahwa mahasiswa sebagai pengguna sistem tersebut merupakan manusia yang memiliki keinginan, harapan dan kebutuhan yang berbeda- beda, serta tidak jarang keinginan, harapan, dan kebutuhan mereka itu mengalami perubahan dari waktu kewaktu dan dalam jangka waktu yang tidak lama. Oleh karena itu suatu perusahaan atau perguruan tinggi harus senantiasa memperhatikan setiap kebutuhan dan harapan yang diinginkan oleh mahasiswanya (user) agar dapat menyajikan suatu sistem yang dapat memenuhi kebutuhan (user) dalam rangka meningkatkan kepuasan mahasiswa (user) agar dapat meningkatkan pula kinerja yang dihasilkannya. Istilah end user (pengguna) mulai dikenal pada akhir tahun 1970. end user merupakan pengguna yang menggunakan produk akhir suatu sistem informasi berbasis komputer Mc Leod (2007). Kepuasan pengguna merupakan salah satu faktor yang penting dalam mengukur kesuksesan suatu sistem informasi Xiao dan Dasgupta dalam Wahyudi, R., Astuti, E.S., dan Riyadi (2015). Para peneliti yang menggunakan pendekatan ini berasumsi bahwa pengguna yang puas akan memiliki kinerja yang lebih baik dibandingkan dengan pengguna yang merasa tidak puas terhadap sistem informasi, dan sistem informasi dikatakan sukses apabila mampu membantu pengguna untuk menghasilkan kinerja yang lebih baik. Untuk dapat mengukur kepuasan pengguna, dapat dilakukan dengan indikator-indikator kepuasan. Indikator yang digunakan untuk variabel kepuasan Tjiptono (2011) adalah kepuasan terhadap jasa, kesediaan konsumen untuk merekomendasikan kepada orang lain, dan tingkat konfirmasi harapan”.

\section{Kualitas Sistem}

Kualitas menurut Assauri (2004) pengertian kualitas adalah kualitas diartikan sebagai faktor-faktor yang terdapat dalam suatu barang atau hasil yang menyebabkan barang atau hasil tersebut sesuai dengan tujuan untuk apa barang atau hasil itu dimaksudkan atau dibutuhkan. Menurut Supranto (2006) adalah sebuah kata yang bagi penyedia jasa merupakan sesuatu yang harus dikerjakan dengan baik. Sebagai sebuah sistem, maka tentu saja masalah kualitas mencakup berbagai unsur atau elemen yang satu sama lain saling tergantung dan saling mempengaruhi sehingga apa yang terjadi pada salah satu elemen atau unsur akan mempengaruhi kondisi atau keadaan pada elemen atau unsur lainnya. Sedangkan system menurut Jogiyanto (2005) adalah suatu jaringan kerja dari prosedurprosedur yang saling berhubungan, berkumpul bersama- sama untuk melakukan suatu kegiatan atau untuk menyelesaikan suatu sasaran tertentu. Jika dalam sebuah sistem terdapat elemen yang tidak memberikan manfaat dalam mencapai tujuan yang sama, maka elemen tersebut dapat dipastikan bukanlah bagian dari sistem. Berdasarkan definisi-definisi diatas maka terlihat jelas bahwa suatu sistem berkualitas jika sistem yang dihasilkan tersebut sesuai dengan tujuan untuk apa hasil itu dimaksudkan atau dibutuhkan serta dikerjakan dengan baik. Kualitas sistem merupakan kesesuaian terhadap karakter jasa yang harus dikerjakan dengan baik pada suatu jaringan kerja dari prosedur- prosedur yang saling berhubungan, berkumpul bersama-sama untuk melakukan suatu kegiatan atau untuk menyelesaikan suatu sasaran tertentu. Menurut DeLone dan McLean (2003) adapun indikator yang dapat digunakan untuk mengukur kualitas system yaitu: 1) kemudahan untuk digunakan (ease of use); 2) kemudahan untuk diakses (system flexibility); 3) kecepatan akses (response time); 4) dan ketahanan dari kerusakan (reliability). Selain itu juga digunakan indikator lain yaitu keamanan sistem (security).

\section{Kualitas Informasi}

McLeod, R., dan Schell (2007) menyatakan bahwa informasi adalah data yang telah diolah menjadi bentuk yang memiliki arti bagi penerima dan bermanfaat bagi pengambilan keputusan saat ini atau mendatang. Didalam online shopping sebaiknya menyajikan informasi yang mencakup kaitannya dengan produk dan jasa yang ada pada online shopping. Informasi tersebut sebaiknya berguna dan relevan dalam memprediksi kualitas dan kegunaan produk atau jasa.Informasi produk dan jasa harus up-to-date untuk memuaskan kebutuhan konsumen atau pembeli online. Hal tersebut dapat membantu pembeli didalam membuat keputusan, konsisten dan mudah dipahami. Kualitas informasi adalah sejauh mana informasi secara konsisten dapat memenuhi persyaratan dan harapan semua orang yang membutuhkan informasi tersebut untuk melakukan proses mereka. Konsep ini dikaitkan dengan konsep produk informasi yang menggunakan data sebagai masukan dan informasi didefinisikan sebagai data yang telah diolah sehingga memberikan makna bagi penerima informasi (Wardoyo, dan Andini, I., 2017). Menurut Aimsyah (2013) kualitas informasi ditentukan oleh empat karakteristik, yaitu: 1) Akurat (Accuracy): Artinya informasi harus mencerminkan keadaan yang sebenarnya. Pengujian akurasi dilakukan oleh dua orang atau lebih yang berbeda, apabila pengujian tersebut menghasilkan hasil yang sama maka data tersebut dianggap akurat; 2) Timely (tepat waktu): Informasi yang dihasilkan tidak boleh terlambat (usang) sebab informasi yang sudah usang tidak mempunyai nilai yang baik; 3) Relevant (relevan): Artinya informasi yang diberikan harus sesuai dengan yang dibutuhkan oleh 
individu yang ada diberbagai tingkatan dan bagian dalam organisasi; dan 4) Complete (lengkap): Artinya informasi harus diberikan secara lengkap. Misalnya informasi tentang penjualan tidak ada bulannya atau tidak ada fakturnya.

\section{Kualitas Layanan}

Kualitas pelayanan merupakan suatu hal penting yang harus diperhatikan oleh setiap perusahaan. Service quality adalah sebuah penilaian apa yang konsumen terima dengan apa yang konsumen harapkan saling bersesuaian atau berlawanan. Bagi para perusahaan pelayanan jasa, perusahaan benar-benar dituntut oleh konsumennya untuk memberikan kualitas pelayanan yang maksimal, memberikan pelayanan yang baik mampu membedakan perusahaan dengan pesaing dan membentuk positioning bagi perusahaan. Menurut Wood (2009) pada dasarnya setiap interaksi dengan pelanggan adalah sebuah bentuk dari layanan pelanggan. Bentuk interaksi tersebut bermacam-macam, bisa lewat telpon, surat, email atau tatap muka langsung. Semua bentuk kontak dengan pelanggan ini memikul tanggung jawab yang sama terhadap persepsi konsumen mengenai suatu bisnis dan tingkat kepuasan keseluruhan yang mereka rasakan ketika berhubungan dengan bisnis itu. Layanan pelanggan adalah benar-benar tentang memuaskan kebutuhan pelanggan anda dan melampaui harapan-harapan mereka. Menurut Stanton (2006) "layanan adalah kegiatan yang dapat didefinisikan secara tersendiri yang pada hakekatnya bersifat tak teraba (intangible), yang merupakan pemenuhan kebutuhan, dan tidak harus terikat penjualan produk atau jasa lain". Sedangkan menurut Kotler, definisi pelayanan adalah setiap tindakan atau kegiatan yang dapat ditawarkan oleh suatu pihak kepada pihak lain, yang pada dasarnya tidak berwujud dan tidak mengakibatkan kepemilikan apapun (Kotler, 2010). Menurut Zeithaml, Berry, dan Parasuraman dalam Tjiptono (2011), untuk mengevaluasi kualitas jasa pelanggan umumnya menggunakan 5 dimensi yaitu Tangibles, Reliability, Responsiveness, Assurance, dan Emphaty.

\section{Hipotesis}

Berdasarkan pada kerangka pemikiran teoritis diatas, maka hipotesis penelitian yang diajukan dalam penelitian ini adalah sebagai berikut:

1. Kualitas sistem secara parsial berpengaruh terhadap kepuasan mahasiswa.

2. Kualitas informasi secara parsial berpengaruh terhadap kepuasan mahasiswa.

3. Kualitas layanan secara parsial berpengaruh terhadap kepuasan mahasiswa.

4. Kualitas system, kualitas informasi dan kualitas layanan secara simultan berpengaruh terhadap kepuasan mahasiswa.

\section{Metode}

Metode yang digunakan dalam penelitian ini adalah metode survey dengan pendekatan kuantitatif. Penelitian kuantitatif dilakukan dengan menggunakan teknik korelasi. Teknik ini dilakukan untuk menganalisa hubungan antara tiga variabel independent yakni kualitas sistem $\left(\mathrm{X}_{1}\right)$, kualitas informasi $\left(\mathrm{X}_{2}\right)$, dan kualitas layanan $\left(\mathrm{X}_{3}\right)$ terhadap kepuasan mahasiswa sebagai variabel terikat. Penelitian ini sendiri dilakukan di Universitas Batanghari Jambi, dengan unit analisis adalah mahasiswa/i dilingkungan Universitas Batanghari Jambi. Ukuran sampel pada penelitian ini ditentukan menggunakan teknik proportionate random sampling untuk masing-masing Fakultas dengan total sampel sebanyak 98 orang mahasiswa. Teknik analisis data dalam penelitian menggunakan persamaan regresi linear berganda, dengan persamaan $Y=a+b_{1} X_{1}+b_{2} X_{2}+b_{3} X_{3}+e$ dimana $\mathrm{Y}$ adalah variable kepuasan mahasiswa, $\beta_{1}, \beta_{2}$ dan $\beta_{3}$ koefisien variable kompensasi $\left(\mathrm{X}_{1}\right)$, kualitas sistem $\left(\mathrm{X}_{1}\right)$, kualitas informasi $\left(\mathrm{X}_{2}\right)$, dan kualitas layanan $\left(\mathrm{X}_{3}\right)$. Alat bantu analisis data program aplikasi SPSS versi 21.0 for windows. Setelah dianalisis dengan Regresi linear berganda, dilanjutkan dengan uji analisis determinasi ( $R$ Square), pengujian hipotesis secara parsial (uji t) dan simultan (uji F) dengan tingkat toleransi error 5 persen. Namun sebelum proses Regresi linear berganda terlebih dahulu di uji instrumen penelitian (kuesioner) dengan uji validitas dan realibilitas serta asumsi klasik melalui uji normalitas, multikolinearitas, dan heterokedastisitas.

\section{Hasil}

Secara umum pilihan responden terhadap kuesioner yang disebarkan pada Universitas Batanghari Jambi direspon setuju dan sangat setuju pada butir-butir kuesioner. Hal ini menunjukkan bahwa kualitas system, kualitas informasi, kualitas layanan, dan kepuasan telah berjalan sesuai dengan persepsi responden.

Berdasarkan hasil analisis didapatkan bahwa:

1) Berdasarkan sebaran kuesioner yang dilakukan diketahui bahwa responden memberikan jawaban dengan kategori setuju dan sangat setuju untuk variable kualitas system. Hal ini memberikan indikasi bahwa responden memberikan persepsi yang baik terhadap kualitas sistem yang ada pada SITA Unbari Jambi. Artinya kualitas system yang ada pada SITA Unbari Jambi dinilai baik. Adanya kemudahan dalam menggunakan SITA, adanya 
kemudahan dalam mengakses SITA, SITA dapat diakses melalui Phonsel, SITA dapat diakses dengan cepat, serta SITA dapat dibuka setiap saat.

2) Dari hasil sebaran kuesioner yang dilakukan diketahui bahwa mayoritas responden memberikan jawaban dengan kategori sangat setuju variable kualitas informasi. Hal ini ini memberikan indikasi bahwa kualitas informasi yang ada pada SITA Unbari Jambi dinilai baik. SITA memunculkan informasi Akademik setiap semester dengan baik, Informasi yang disajikan pada SITA selalu Update, Informasi yang ada pada SITA sesuai dengan yang dibutuhkan oleh mahasiswa, dan Informasi yang ada pada SITA dapat dengan mudah dipahami.

3) Berdasarkan sebaran kuesioner yang dilakukan diketahui bahwa mayoritas responden memberikan jawaban dengan kategori setuju dan sangat setuju untuk variable kualitas layanan. Hal ini memberikan indikasi bahwa kualitas pelayanan yang ada pada Unbari Jambi dinilai baik. Adanya rasa nyaman dengan kondisi gedung perkuliahan, ruang tempat belajar terasa nyaman, pelayanan administrasi dapat diandalkan, petugas administrasi dapat memahami kesulitan mahasiswa, serta petugas administrasi dapat memberikan kelancaran proses semestinya.

4) Berdasarkan sebaran kuesioner yang dilakukan diketahui bahwa sebagian besar responden memberikan jawaban dengan kategori setuju. Hal ini memberikan indikasi bahwa mahasiswa telah merasa puas dengan system informasi yang ada pada SITA Unbari Jambi saat ini. Informasi yang disajikan pada SITA mudah dipahami, tampilan pelayanan pada Siakad SITA komunikatif, kotak dialog pada SITA menarik, menu bantuan yang ada dalam SITA tersedia dengan jelas, adanya rasa senang dengan layanan SITA. Serta jika ada teman yang tidak paham tentang layanan Akademik, saya akan menyarankan untuk membuka SITA.

Persyaratan untuk menggunakan analisis regresi berganda adalah terpenuhinya asumsi klasik. Untuk mendapatkan nilai pemeriksa yang efisien dan tidak bias atau BLUE (Best Linear Unbias Estimator) dari satu persamaan regresi berganda dengan metode kuadrat terkecil (least square), maka perlu dilakukan pengujian untuk mengetahui model regresi yang dihasilkan memenuhi persyaratan asumsi klasik. Dalam penelitian ini akan di kemukakan uji asumsi klasik yang umum digunakan, yaitu Uji Normalitas Uji Muktikolinearitas dan Uji Heterokedastisitas dengan menggukan SPSS 21.0 sebagai alat bantu dalam penelitian ini.

1. Hasil uji yang dilakukan dengan menggunkan bantuan SPSS 21.0 sebagai alat bantu dalam penelitian ini diperoleh hasil bahwasanya data dalam penelitian ini berdistribusi normal, hal ini dibuktikan dari hasil nilai signifikansi (Asymp. Sig. 2-tailed) lebih besar dari 0,05, yaitu $(0,886>0,05)$ sehingga dapat disimpulkan bahwa data dalam penelitian ini berdistribusi normal.

2. Hasil uji multikolinearitas diketahui bahwasanya hasil perhitungan nilai Tolerance menunjukan tidak ada variabel independent yang memiliki nilai Tolerance kurang dari 0.10, yang berarti tidak ada korelasi antar variabel independent. Selain itu pula hasil perhitungan nilai Variance Inflation Factor (VIF) juga menunjukan hal yang sama tidak ada satu variabel independent yang memiliki nilai VIF lebih dari 10. Jadi dapat disimpulkan bahwa tidak terjadi multikolinearitas antar variabel Independent dalam model regresi.

3. Hasil uji heterokedastisitas diketahui scatterplots terlihat bahwa titik-titik menyebar secara acak serta tresebar baik diatas maupun dibawah angka 0 pada sumbu Y. hal ini dapat disimpulkan bahwa tidak terjadi heterokedastisitas pada model regresi, sehingga model regresi layak dipakai untuk memprediksi Penggunaan jasa akomodasi berdasarkan masukan variabel independent.

Berdasarkan dari pengujian tersebut telah terbukti bahwa model persamaan yang diajukan dalam penelitian ini telah memenuhi persyaratan asumsi klasik sehingga model persamaan dalam penelitian ini sudah dianggap baik. Analisis regresi liner berganda digunakan untuk menguji hipotesis pengaruh secara parsial dan simultan variabel bebas terhadap variabel terikat. Dalam pengujian hipotesis, penelitian ini memberikan asumsi bahwa tingkat signifikansi hipotesis alternatif yang diterima adalah dibawah 0,05 atau 5\%. Hasil analisa regresi bertingkat tersebut dapat diringkas pada Tabel 1 berikut:

Tabel 1

Hasil Analisa Regresi Linear Berganda

\begin{tabular}{|c|c|c|c|c|c|}
\hline Variabel Terikat & Variabel Bebas & Koefisien Regresi & $\mathbf{t} / \mathbf{F}_{\text {hitung }}$ & Signifikansi & Hipotesis \\
\hline \multirow{8}{*}{$\begin{array}{l}\text { Kepuasan Mahasiswa } \\
\text { (Y) }\end{array}$} & Konstanta (a) & 5,150 & & & - \\
\hline & Kualitas Sistem $\left(\mathrm{X}_{1}\right)$ & 0,164 & 2,359 & 0,020 & Diterima \\
\hline & Kualitas Informasi $\left(\mathrm{X}_{2}\right)$ & 0,346 & 2,955 & 0,004 & Diterima \\
\hline & Kualitas Layanan $\left(\mathrm{X}_{3}\right)$ & 0,538 & 7,092 & 0,000 & Diterima \\
\hline & $\mathrm{F}$ & 70,110 & & 0,000 & Diterima \\
\hline & Adjusted $\mathrm{R}^{2}$ & 0,681 & & & \\
\hline & $\mathrm{t}_{\text {tabel }}$ & 1,9849 & & & \\
\hline & $\mathrm{F}_{\text {tabel }}$ & 2,70 & & & \\
\hline
\end{tabular}

Sumber: Data Olahan 
Tabel 1 di atas diperoleh hasil persamaan regresi linear berganda : $Y=\alpha+\beta_{1} X_{1}+\beta_{2} X_{2}+\beta_{3} X_{3}+e=5,150$ $+0,164 \cdot X_{1}+0,346 \cdot X_{2}+0,538 \cdot X_{3}+$ e. Keterangan: $Y=$ kepuasan mahasiswa; $X_{1}=$ kualitas sistem, $X_{2}=$ kualitas informasi, dan $\mathrm{X}_{3}=$ kualitas layanan. Dari persamaan ini dapat diinterpretasikan:

1) Konstanta sebesar 5,150 menunjukkan jika variabel independen atau bebas kualitas sistem $\left(X_{1}\right)$, kualitas informasi $\left(\mathrm{X}_{2}\right)$, dan kualitas layanan $\left(\mathrm{X}_{3}\right)$ diabaikan atau diasumsikan 0 maka besar $\mathrm{Y}$ adalah 5,150 artinya sebelum atau tanpa adanya variabel kualitas sistem $\left(\mathrm{X}_{1}\right)$, kualitas informasi $\left(\mathrm{X}_{2}\right)$, dan kualitas layanan $\left(\mathrm{X}_{3}\right)$ dalam Universitas Batanghari maka besarnya kepuasan mahasiswa (Y) akan sebesar 5,150.

2) Kualitas Sistem $\left(X_{1}\right)=0,164$, merupakan koefisien regresi variabel kualitas sistem $\left(X_{1}\right)$ terhadap variabel kepuasan (Y). Yang memiliki makna bahwa setiap penambahan satu nilai kualitas sistem akan menaikan nilai kepuasan mahasiswa sebesar 0,164, atau dengan kata lain apabila kualitas sistem dapat ditingkatkan kualitasnya sebesar 100 skala, maka hal itu akan diikuti pula dengan peningkatan kepuasan mahasiswa sebesar 100 skala.

3) Kualitas Informasi $\left(X_{2}\right)=0,346$, merupakan koefisien regresi variabel kualitas informasi $\left(X_{2}\right)$ terhadap variabel kepuasan (Y). Yang memiliki makna bahwa setiap penambahan satu nilai kualitas informasi akan menaikan nilai kepuasan mahasiswa sebesar 0,346, atau dengan kata lain apabila kualitas informasi yang disajikan pada SITA UNBARI dapat ditingkatkan kualitasnya sebesar 100 skala, maka hal itu akan diikuti pula dengan peningkatan kepuasan mahasiswa sebesar 100 skala.

4) Kualitas Pelayanan $\left(X_{3}\right)=0,538$, merupakan koefisien regresi variabel kualitas pelayanan $\left(X_{3}\right)$ terhadap variabel kepuasan (Y). Yang memiliki makna bahwa setiap penambahan satu nilai kualitas pelayanan akan meningkatkan nilai kepuasan mahasiswa sebesar 0,538, atau dengan kata lain apabila UNBARI dapat meningkatkan kualitas pelayanannya sebesar 100 skala, maka hal itu akan diikuti pula dengan peningkatan kepuasan mahasiswa sebesar 100 skala.

5) Nilai Adjusted R Square adalah 0,681. Hal ini dapat diinterpretasikan bahwa besarnya pengaruh ketiga variabel bebas yaitu kualitas sistem, kualitas informasi, dan kualitas layanan terhadap kepuasan mahasiswa adalah $68,1 \%$. Sedangkan sisanya sebesar 31,9\% dipengaruhi oleh variabel lain yang tidak termasuk kedalam ruang lingkup penelitian ini.

Pengujian hipotesis bertujuan untuk menjelaskan karakteristik hubungan-hubungan tertentu atau perbedaanperbedaan antar kelompok atau independensi dari dua faktor atau lebih dalam suatu situasi (Ali, H., Limakrisna, $\mathrm{N}$. 2013). Dimana pengujian hipotesis pengujian pengaruh parsial bertujuan untuk menguji pengaruh masing-masing variabel independent terhadap variabel terikat. Sedangkan secara simultan dilakukan untuk mengetahui pengaruh beberapa variabel independent secara bersama-sama dengan $\alpha=0,05$ dan juga penerimaan atau penolakan hipotesis.

Tabel 1 diatas dengan diperoleh angka $t_{\text {hitung }}$ variabel kualitas sistem sebesar 2,359 lebih besar dari tabel atau 2,359 > 1,9849 dengan tingkat signifikansi sebesar 0,020. Nilai signifikansi tersebut lebih kecil dari alpha 0,05. Dengan demikian, dapat diartikan bahwa kualitas sistem $\left(\mathrm{X}_{1}\right)$ berpengaruh positif dan signifikan terhadap kepuasan mahasiswa (Y). Oleh karena itu hipotesis yang menyatakan bahwa kualitas sistem secara parsial berpengaruh signifikan terhadap kepuasan mahasiswa Universitas Batanghari Jambi, diterima. Hasil penelitian ini menunjukan hasil yang sama dengan penelitian yang dilakukan oleh Asnawi, M.F (2014), Khairrunisa, U dan Yunanto, M (2017), Septianita, W., Winarno, W.A., dan Arif, A (2014), dan Fendini, D.S., Kertahadi., dan Riyadi (2013) dimana hasil penelitian menyatakan bahwa kualitas sistem memiliki pengaruh yang positif dan signifikan terhadap kepuasan pengguna.

Hasil penelitian ini juga sejalan dengan penelitian yang dilakukan oleh DeLone dan McLean (1992) yang membuktikan bahwa kualitas sistem akan berpengaruh terhadap kepuasan pengguna. Kualitas sistem dapat diukur dari sisi kecepatan akses (response time), kehandalan sistem (system reliability), kemudahan untuk digunakan (ease to use), kemudahan untuk diakses (system flexibility), dan keamanan sistem (system security). Berdasarkan hasil survey yang dilakukan kualitas sistem yang ada pada SITA Unbari Jambi dapat dikategorikan baik. Hal ini menjelaskan bahwasanya SITA Unbari Jambi dapat memberikan kemudahan bagi mahasiswa dalam menggunakan SITA, selain itu adanya kemudahan dalam mengakses SITA. SITA dapat diakses melalui Phonsel, SITA dapat diakses dengan cepat, serta SITA dapat dibuka setiap saat. Kualitas sistem merupakan karakteristik dari informasi yang melekat mengenai sistem itu sendiri yang mana kualitas sistem merujuk pada seberapa baik kemampuan perangkat keras, perangkat lunak, dan kebijakan prosedur dari sistem informasi yang dapat menyediakan informasi kebutuhan pemakai (Delone dan McLean, 1992).

Tabel 1 diatas dengan diperoleh angka $t_{\text {hitung }}$ variabel kualitas informasi sebesar 2,955 lebih besar dari $t_{\text {tabel }}$ atau 2,955 > 1,9849 dengan tingkat signifikansi sebesar 0,004. Nilai signifikansi tersebut lebih kecil dari alpha 0,05. Dengan demikian, dapat diartikan bahwa kualitas informasi $\left(\mathrm{X}_{2}\right)$ berpengaruh positif dan signifikan terhadap kepuasan mahasiswa (Y). Oleh karena itu hipotesis yang menyatakan bahwa kualitas informasi secara parsial berpengaruh signifikan terhadap kepuasan mahasiswa Universitas Batanghari Jambi, diterima. Hasil penelitian ini sejalan dengan 
penelitian yang dilakukan oleh Asnawi, M.F (2014), Septianita, W., Winarno, W.A., dan Arif, A (2014), Tulodo, B.A.R., dan Solichin, A (2019), dan Fendini, D.S., Kertahadi., dan Riyadi (2013) yang menyatakan bahwa kualitas informasi memiliki pengaruh yang positif dan signifikan terhadap kepuasan pengguna.

Berdasarkan hasil survey yang dilakukan kualitas informasi yang ada pada SITA Unbari Jambi termasuk pada kategori baik. Hal ini menjelaskan bahwasanya responden memberikan persepsi yang baik terhadap kualitas informasi yang ada pada SITA Unbari Jambi. Artinya kualitas informasi yang ada pada SITA Unbari Jambi dinilai baik. SITA memunculkan informasi Akademik setiap semester dengan baik, Informasi yang disajikan pada SITA selalu Update, Informasi yang ada pada SITA sesuai dengan yang dibutuhkan oleh mahasiswa, dan Informasi yang ada pada SITA dapat dengan mudah dipahami. Kualitas informasi adalah sejauh mana informasi secara konsisten dapat memenuhi persyaratan dan harapan semua orang yang membutuhkan informasi tersebut untuk melakukan proses mereka. Konsep ini dikaitkan dengan konsep produk informasi yang menggunakan data sebagai masukan dan informasi didefinisikan sebagai data yang telah diolah sehingga memberikan makna bagi penerima informasi (Wardoyo, dan Andini, I., 2017).

Tabel 1 diatas dengan diperoleh angka $t_{\text {hitung }}$ variabel kualitas layanan sebesar 7,092 lebih besar dari $t_{\text {tabel }}$ atau 7,092 > 1,9849 dengan tingkat signifikansi sebesar 0,000. Nilai signifikansi tersebut lebih kecil dari alpha 0,05. Dengan demikian, dapat diartikan bahwa kualitas layanan $\left(\mathrm{X}_{3}\right)$ berpengaruh positif dan signifikan terhadap kepuasan mahasiswa (Y). Oleh karena itu hipotesis yang menyatakan bahwa kualitas layanan secara parsial berpengaruh signifikan terhadap kepuasan mahasiswa Universitas Batanghari Jambi, diterima. Hasil penelitian ini sejalan dengan penelitian yang dilakukan oleh Asnawi, M.F (2014), dan Septianita, W., Winarno, W.A., dan Arif, A (2014) yang menyatakan bahwa kualitas layanan memiliki pengaruh yang positif dan signifikan terhadap kepuasan pengguna. Berdasarkan hasil survey yang dilakukan kualitas layanan yang ada dapat dikategorikan baik. Hal ini menjelaskan bahwasanya responden memberikan persepsi yang baik terhadap kualitas pelayanan yang ada pada Unbari Jambi. Artinya kualitas pelayanan yang ada pada Unbari Jambi dinilai baik. Adanya rasa nyaman dengan kondisi gedung perkuliahan, ruang tempat belajar terasa nyaman, pelayanan administrasi dapat diandalkan, petugas administrasi dapat memahami kesulitan mahasiswa, serta petugas administrasi dapat memberikan kelancaran proses semestinya.

Kualitas pelayanan merupakan suatu hal penting yang harus diperhatikan oleh setiap perusahaan. Service quality adalah sebuah penilaian apa yang konsumen terima dengan apa yang konsumen harapkan saling bersesuaian atau berlawanan. Bagi para perusahaan pelayanan jasa, perusahaan benar-benar dituntut oleh konsumennya untuk memberikan kualitas pelayanan yang maksimal, memberikan pelayanan yang baik mampu membedakan perusahaan dengan pesaing dan membentuk positioning bagi perusahaan. Menurut Stanton (2006) layanan adalah kegiatan yang dapat didefinisikan secara tersendiri yang pada hakekatnya bersifat tak teraba (intangible), yang merupakan pemenuhan kebutuhan, dan tidak harus terikat penjualan produk atau jasa lain. Sedangkan menurut Kotler, definisi pelayanan adalah setiap tindakan atau kegiatan yang dapat ditawarkan oleh suatu pihak kepada pihak lain, yang pada dasarnya tidak berwujud dan tidak mengakibatkan kepemilikan apapun (Kotler, 2010). Menurut Zeithaml, Berry, dan Parasuraman dalam Tjiptono (2011), untuk mengevaluasi kualitas jasa pelanggan umumnya menggunakan 5 dimensi yaitu "Tangibles, Reliability, Responsiveness, Assurance, dan Emphaty.

Tabel 1 di atas dapat dilihat bahwa signifikansi $\mathrm{F}$ adalah 0,000 lebih kecil dari tingkat hipotesis alternatif yaitu $0,000<0,5$ dengan $\mathrm{F}$ hitung sebesar 70,110 dan $\mathrm{F}_{\text {tabel }}$ sebesar 2,70. Dengan demikian dapat diartikan bahwa kualitas sistem $\left(\mathrm{X}_{1}\right)$, kualitas informasi $\left(\mathrm{X}_{2}\right)$ dan kualitas layanan $\left(\mathrm{X}_{3}\right)$ secara bersama-sama atau simultan berpengaruh signifikan terhadap kepuasan mahasiswa (Y). Oleh karena hipotesis (H1) yang menyatakan bahwa kualitas sistem, kualitas informasi dan kualitas layanan secara simultan berpengaruh signifikan terhadap kepuasan mahasiswa. Dengan demikian maka hipotesis keempat terbukti dan dapat diterima. Hal ini menunjukan jika Universitas Batanghari Jambi mampu mengimplementasikan kualitas sistem, kualitas informasi dan kualitas layanan dengan baik, maka secara bersama-sama akan mampu meningkatkan kepuasan mahasiswa, yang ditunjukan dengan adanya rasa puas terhadap jasa, kesediaan untuk merekomendasikan kepada orang lain, dan tingkat konfirmasi harapan.

Berdasarkan hasil survey yang dilakukan kepuasan mahaswiswa dalam menggunakan SITA Unbari Jambi termasuk pada kategori puas. Hal ini menjelaskan bahwasanya responden memberikan persepsi yang puas terhadap kualitas informasi yang ada pada SITA Unbari Jambi. Artinya mahasiswa telah merasa puas dengan sistem informasi yang ada pada SITA Unbari Jambi saat ini. Informasi yang disajikan pada SITA mudah dipahami, tampilan pelayanan pada Siakad SITA komunikatif, kotak dialog pada SITA menarik, menu bantuan yang ada dalam SITA tersedia dengan jelas, adanya rasa senang dengan layanan SITA. Menciptakan dan mencapai kepuasan mahasiswa sebagai pengguna suatu sistem yang diterapkan suatu perguruan tinggi, bukanlah suatu hal yang mudah bagi perusahaan tersebut, mengingat bahwa mahasiswa sebagai pengguna sistem tersebut merupakan manusia yang memiliki keinginan, harapan dan kebutuhan yang berbeda- beda, serta tidak jarang keinginan, harapan, dan kebutuhan mereka itu mengalami perubahan dari waktu kewaktu dan dalam jangka waktu yang tidak lama. Oleh karena itu suatu perusahaan atau perguruan tinggi harus senantiasa memperhatikan setiap kebutuhan dan harapan yang diinginkan oleh 
Osrita Hapsara et al, Analisis Kepuasan Mahasiswa dalam Menggunakan Sistem Informasi Terpadu Akademik (SITA) Universitas Batanghari Jambi

mahasiswanya (user) agar dapat menyajikan suatu sistem yang dapat memenuhi kebutuhan (user) dalam rangka meningkatkan kepuasan mahasiswa (user) agar dapat meningkatkan pula kinerja yang dihasilkannya.

\section{Simpulan}

Berdasarkan hasil penelitian dan pembahasan, maka dapat disimpulkan sebagai berikut:

1. Terdapat pengaruh yang signifikan antara kualitas sistem terhadap Kepuasan mahasiswa. Hal ini menjelaskan bahwasanya, apabila kualitas sistem mengalami peningkatan maka kepuasan mahasiswa akan bertambah. Dengan kata lain kualitas sistem akan sangat mempengaruhi dalam kepuasan pengguna. Jika pengguna yakin dengan kualitas sistem yang digunakan, maka mereka akan semakin sering menggunakan sistem tersebut, karena hasil olahan informasinya yang memuaskan.

2. Terdapat pengaruh yang signifikan antara variabel kualitas informasi terhadap kepuasan mahasiswa. Hasil ini menjelaskan bahwasanya apabila kualitas informasi yang disajikan pada sistem informasi mengalami peningkatan, maka hal ini akan meningkatan pula kepuasan mahasiswa dalam menggunakan system informasi tersebut. Artinya jika informasi yang dihasilkan oleh sistem informasi semakin akurat, tepat waktu, kelengkapan yang baik, maka akan semakin meningkatkan kepuasan pengguna

3. Terdapat pengaruh yang signifikan antara kualitas layanan terhadap kepuasan mahasiswa. Hal ini menjelaskan apabila kualitas layanan yang ada mengalami peningkatan pada sistem informasi yang ada, maka akan meningkatan kepuasan mahasiswa sebagai pengguna. Artinya Jika kualitas layanan yang dihasilkan oleh sistem informasi semakin handal, berwujud, empati, daya tanggap dan jaminan yang baik, maka akan semakin meningkatan kepuasan mahasiswa sebagai pengguna.

4. Kualitas sistem, kualitas informasi dan kualitas layanan secara bersama-sama memiliki pengaruh terhadap kepuasan mahasiswa. Dimana kualitas layanan memiliki pengaruh yang lebih dominan dalam meningkatkan kepuasan mahasiswa dibandingkan kualitas sistem dan kualitas informasi.

\section{Daftar Pustaka}

Aimsyah, Z. 2013. Manajemen Sistem Informasi. Jakarta: PT. Gramedia Pustaka.

Akbar, M.M., dan Parvez, N. 2009. Impact of Services Quality, Trust, and Customer Satisfaction on Customer Loyalty, ABAC Journal, Vol. 29, No. 1, pp. 24-38.

Ali, H., dan Limakrisna, N. 2013. Metodologi Penelitian (Petunjuk Praktis untuk Pemecahan Masalah Bisnis, Penyusunan Skripsi, Tesis, dan Disertasi. Deeppublish: Yogyakarta.

Arikunto, Suharsimi. 2012. Prosedur Penelitian Suatu Pendekatan Praktek. Jakarta: Rineka Cipta.

Asnawi, M.F. 2014. Pengaruh Kualitas Sistem, Kualitas Informasi, Kualitas Layanan, dan Partisipasi Pengguna Terhadap Kepuasan Pengguna Sistem: Studi Kasus Pada Bagian Operasional VSAT IP PT. Semestas Citra Media. Jurnal Lentera ICT, Vol. 2, No. 1.

Assauri, Sofjan. 2004. Manajemen Pemasaran. Jakarta: Rajawali Press.

DeLone, W.H and McLean, E.R. 2003. The DeLone and McLean Model of Sistem Success: A Ten-Year Update, Journal of Mangement Information Sistem, 19 (4), 9-30.

Engel, J.F, Blackwell, Rd, and Miniard, DW. 2010. Perilaku Konsumen. Jilid I. (Boediono. Terjemahan). Jakarta: Bina Rupa Aksara.

Fendini, D.S., Kertahadi., dan Riyadi. 2013. Pengaruh Kualitas Sistem dan Kualitas Informasi Terhadap Kepuasan Pengguna (Surveu pada Karyawan Pengguna Aplikasi Pelayanan Pelanggan Terpusat (AP2T) di PT PLN (Persero) Area Malang).

Ferdinand, A. 2014. Metode Penelitian Manajemen: Pedoman Penelitian untuk Skripsi, Tesis dan Disertasi Ilmu Manajemen. Semarang: Badan Penerbit Universitas Diponegoro.

Ghozali, I. 2013. Aplikasi Analisis Multivariate Dengan Program SPSS. Semarang: Penerbit Undip.

Jogiyanto, HM. 2007. Model Kesuksesan Sistem Teknologi Informasi. Yogyakarta: Andi.

Khairrunnisa, U., dan Yunanto, M. 2017. Pengaruh Kualitas Sistem Terhadap Kepuasan Pengguna dan Manfaat Bersih pada Implementasi E-Faktur: Validasi Model Kesuksesan Sistem Informasi Delone dan McLean. Jurnal Ekonomi Bisnis, 22(3).

Kotler, P. 2010. Manajemen Pemasaran, diterjemahkan oleh Hendra Teguh dan Ronny A. Rusli. Terjemahan. Jakarta: PT. Prehallindo.

Lovelock.C dan Wright, Lauren K. 2007. Manajemen Pemasaran Jasa, Alih bahasa Agus Widyantoro, Cetakan Kedua, Jakarta; PT. Indeks.

McLeod, R., dan Schell. 2007. Sistem Informasi Manajemen. Jakarta: PT. Indeks.

Park, C.H., dan Kim Y.G. 2003. A Frameworkof dynamic CRM: Linking Marketing With Information Strategy. Business Process Management Journal, 9(5), 652-671. 
Osrita Hapsara et al, Analisis Kepuasan Mahasiswa dalam Menggunakan Sistem Informasi Terpadu Akademik (SITA) Universitas Batanghari Jambi

Riduwan dan Kuncoro, E.K. 2013. Cara Menggunakan dan Memaknai Path Analysis. Alfabeta: Bandung.

Septianita, W., Winarno, W.A., dan Arif, A. 2014. Pengaruh Kualitas Sistem, Kualitas Informasi, Kualitas Pelayanan Rail Ticketing System (RTS) Terhadap Kepuasan Pengguna (Studi Empiris pada PT. Kereta Api Indonesia (Persero) DAOP 9 Jember). E-Journal Ekonomi Bisnis dan Akuntasi, 1(1).

Singarimbun, M dan Effendi, S. 2012. Metode Penelitian Survey. Jakarta: LP3AES.

Solichin, A. 2019. Analisis Pengaruh Kualitas Sistem, Kualitas Informasi dan Perceived Usefulness Terhadap Kepuasan Pengguna Aplikasi Care Dalam Upaya Peningkatan Kinerja Karyawan (Studi Kasus PT. Malacca Trust Wuwungan Insurance, Tbk.) Jurnal Riset Manajemen Sains Indonesia (JRMSI), 10(1).

Stanton, William J. 2006. Prinsip pemasaran, alih bahasa : Yohanes Lamarto. Jakarta: Erlangga.

Sugiyono. 2012. Statistika Untuk Penelitian. Bandung: Alfabeta.

Supranto. J. 2006. Pengukuran Tingkat Kepuasan Pelanggan Untuk Menaikkan Pangsa Pasar. Jakarta: Rineka Cipta.

Tjiptono, F. 2011. Perspektif Manajemen dan Pemasaran Kontemporer. Yogyakarta: Andi.

Umar, H. 2008. Metode riset bisnis: dilengkapi contoh proposal dan riset bidang manajemen dan akuntansi. Jakarta: Gramedia Pustaka Utama.

Wahyudi, R., Astuti, E.S., dan Riyadi. 2015. Pengaruh Kualitas Sistem, Informasi dan Pelayanan SIAKAD Terhadap Kepuasan Mahasiswa (Studi Pada Mahasiswa Program Sarjana Fakultas Ilmu Administrasi, Universitas Brawijaya. Jurnal Administrasi Bisnis (JAB), 23(2).

Wardoyo, dan Andini, I. 2017. Faktor-Faktor Yang Berpengaruh Terhadap Keputusan Pembelian Secara Online Pada Mahasiswa Universitas Gunadarma. DAYA SAING Jurnal. Ekonomi Manajemen Sumber Daya, 19(1).

Wood, I. 2009. Layanan pelanggan: Cara Praktis,Murah Dan Inspiratif Memuaskan Pelanggan Anda. Yogyakarta: Graha Ilmu.

Yuniarti, V.S. 2015. Prilaku Konsumen. Bandung: Pustaka Setia. 